\title{
MODEL OF FORMING THE PROFESSIONAL-ETHIC CULTURE FOR GRAPHIC DESIGNERS IN COLLEGES
}

\author{
Polina Prokhorchuk, \\ Postgraduate student of the Institute of Vocational Education and Training of NAES of Ukraine \\ https://orcid.org/0000-0003-2987-5962 \\ e-mail:pella039@gmail.com
}

\begin{abstract}
Model of forming the professional-ethic culture for graphic designers is described in the context of ethics training for specialists in colleges. While research the following methods are applied: analysis, synthesis, generalisation, systematisation, previous experience studying, questionnaires and expert estimation.

The model structure and maintenance of professional-ethic culture forming for graphic designers are first reasonable in colleges. It consist of following blocks: methodological (professional-ethic culture forming for graphic designers determination), content-technological (pedagogical conditions, technologies, methods, forms and facilities of professional-ethic culture), substantiates the criteria and levels of formation graphic designers' professional-ethic culture. Based on generalising the different theoretical positions laid in the methodological concept of research, the leading conceptual approaches defined its aim and tasks realisation, namely: axiology, culturological, system, sinergistical, activitaly, technological, personality oriented. The sequence process stages of professional-ethic culture forming for graphic designers and their controllability. are described. The worked out model exposes the research work logic in relation to purposeful ethic norms and values development for artistic colleges students; serves for determining the professional-ethic culture as a pedagogical category; forecasts the graphic designers' professional-ethic culture forming results; demonstrates the major semantic blocks of the investigated process; gives an opportunity for clear tracing intercommunications of separate structural constituents. The prospects of the further scientific studies are determined. They cover technology development for planning and providing the ethic oriented professional training for junior graphic specialists in colleges.
\end{abstract}

Keywords: professional education, professional-ethic culture, graphic designers, model, design.

Introduction. The research actuality consists of professional-ethic culture forming for graphic designers while their studying in the colleges of Ukraine and depends on the pedagogical terms complex development that effectively co-operates with other factors for future specialists professional becoming. It is known that determination of all important aspects, indexes and stages for the following process will encourage the appropriate model designing.

Materials. Before describing the pedagogical model process of professional-ethic culture forming for graphic designers, it is necessary to find out the value of the concept "model". It is widely represented in modern scientifically-pedagogical literature. The decision of this task needs also to determine the essence of designing method in pedagogical research.
In general, the Model (lat. modus - measure) is an analogue (chart, sign system, structure) of certain object (to the original), reality fragment, artefacts, culture creation, conceptually-theoretical formations etc. The model is also related to the method of design. In turn, the design is a scientific method of indirect (mediated) research of cognition objects. The direct study is rather impossible, complicated, inefficient or inadvisable - subject, and signor conceivable systems as they recreate, imitate or represent certain descriptions (properties, signs, principles of internals or function) of originals. (Shynkaruk, 7). The academic dictionary of the Ukrainian language (2005) gives the interpretation to the model as a standard for some new reasons - a product of good example. A standard that recreates and imitates the object's structure and action and is used for getting the new knowledge about an 
Aim: purposeful formation of professional and ethical culture of graphic designers in colleges

Leading tasks: systematic development of students' professional and ethical values: sustainable development of motivation for professional ethics; pedagogical management of the processes of forming the professional and ethical culture of future graphic designers in colleges; effective student's compliance with the rules and norms of the professional ethics code of graphic designers; to ensure the development of the creative potential of graphic designers, attracting students to additional forms of training.

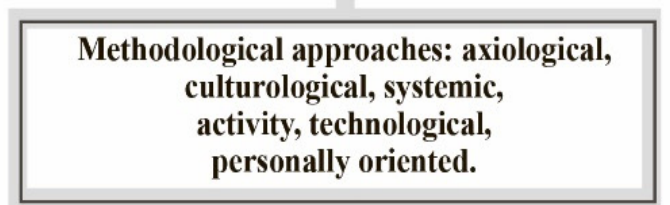

activity, technological
Principles:

morality; problems; motivation; creativity

\section{Pedagogical conditions:}

1) creation of appropriate professional-ethical and creative design environment,

2) formation of positive motivation for professional and ethical improvement, self-perfection and self-development,

3) engaging future graphic designers in production training with the goal accentuation

formation of professional ethical culture.

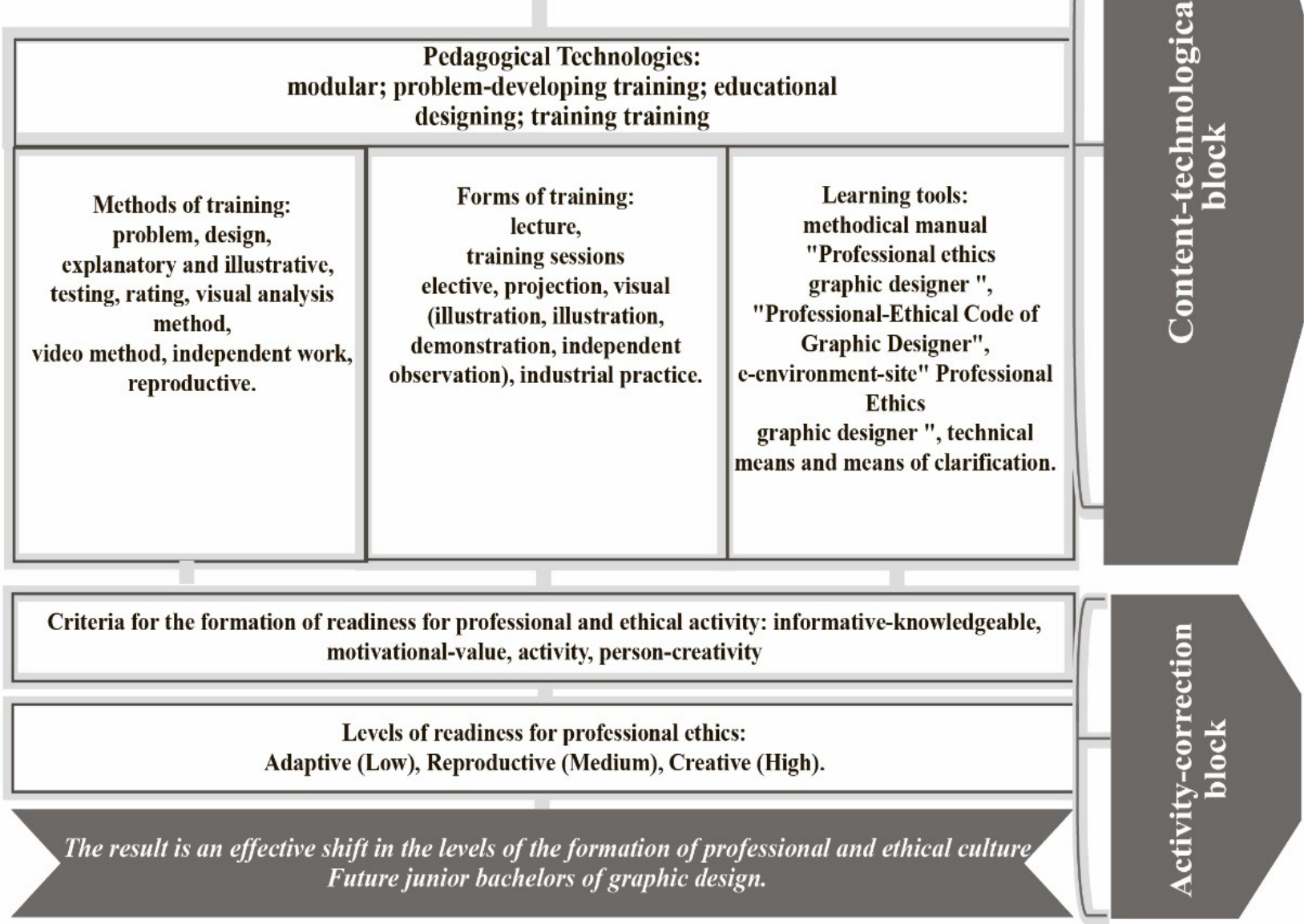

Fig. 1. Model of forming professional-ethic culture for graphic designers in colleges 
object. So, the analysis of references, psychological and pedagogical literature confirms the need in the studying model developing.

The purpose of our article consequently grounds the model of forming professional-ethic culture for junior Bachelors in graphic design.

Methods. The research process foresees the following methods of analysis, synthesis, generalisation, systematisation, previous experience studying, questionnaire and expert estimation.

Results and discussions. Developing the pedagogical model of forming professional-ethic culture for graphic designers envisages taking into account its properties. The following model means the scheme of training ethics for future graphic designers in colleges. It represents the basic structural components of process of professional-ethic culture for graphic designers forming. They are stages, aim, task, methodological approaches, principles, pedagogical terms, pedagogical technologies, methods, forms and facilities of studies, criteria and levels. It makes their successful professional activity possible. The theoretical analysis defines the following basic structural blocks. They are methodological, contenttechnological and activity-correctional (fig. 1).

The methodological block includes the aim as purposeful process of graphic designers' professionalethic culture formation; a task is the systematic development of professional-ethic values for graphic designers while their designing activity and productive studies; pedagogical guidance by the processes of ethic values and norms forming, abilities and skills of a junior Bachelor in graphic design; providing the effective knowledge mastering of ethics activity by students; sustainable students' motivation development for their professional-ethic activity; bringing students to additional professional-ethic activity studies form. The aim and task of the process submit to the modern requirements of the society to professional training quality for future graphic designers in artistic colleges (Fursa, Orlov, 2015).

Made up the methodological concept researches based on different general theoretical positions, certain leading conceptual approaches for its aim and tasks realisation are defined, namely: axiology, culture, system, synergy, activity, technological, personalityoriented. The marked methodological approaches are more detailed considered in the article "Methodological approaches professional-ethic culture forming for graphic designers" (Prokhorcuk, 2019). Thus, the basic principles for graphic designers' professional-ethic culture forming are the problems of morality, motivation and work.

The worked out model includes also a contenttechnological block. It envisages pedagogical terms description, e.g. creating the appropriate professionalethic and creative design environment, forming the positive motivation to professional-ethic perfection; attracting future graphic designers to in-service training with the accent on professional ethic culture forming; (Prokhorchuk, 2018; 2019) selecting the technologies, methods, forms and facilities forming future graphic designers' professional-ethic culture in colleges. (Prokhorchuk, 2016).

Activity-correctional block contains reasonable criteria and levels of graphic designers' professionalethic culture forming. The analysis of pedagogical literature by the theme of research (Kalenskyi, 2016) and taking into account of features of professionalethic culture for future graphic designers in colleges provide us the opportunity to distinguish some criteria of forming graphic designers' professional-ethic culture. They are the motivational-valued (determines the system of values, explains professional-ethic behaviour), informative-knowledge (promotes formation the readiness to be engaged in professional ethics-based activities), activity (assists forming of readiness for realisation the professional activity on ethic principles), personality-creatively (characterizes the ability to self-estimation and creativity in professional ethics) (Kalenskyi, 2016). In accordance with the worked out criteria and taking into account the scientists' opinions in relation the levels of cleared up moral values, it is possible to distinguish the three levels of future graphic designers' already formed professional-ethic culture. They are adaptive (subzero), reproductive (middle) and creative (high).

It is important to notice that the following stages confirm the sequence of graphic designers' professional-ethic culture forming process and its manageability. Thus, the design provides an opportunity to interpret knowledge, check up the defined suppositions and conceptual statements in practice and form the best strategy.

Conclusions. The described model performs several functions, in particular: representing the research logic in relation to purposeful development of ethic norms and values for artistic colleges students; serving determination for professional-ethic culture as a pedagogical category; forecasts the results of professional-ethic culture forming for graphic designers; envisaging the most important content blocks of the investigated process; clear interconnections tracking of individual structural components.

The offered model will be used for methodological, technological and diagnostic aspects of the dissertation research. The appropriate scientific publications will be devoted to that. 


\title{
Список посилань
}

Каленський, А. А., 2016. Компоненти професійно-педагогічної етики. Науковий вісник Національного університету біоресурсів і природокористування Украӥни, 233, с. 106-111.

Фурса, О.О. та Орлов, В. Ф., 2015. Проблеми проектування професійної кар'єри майбутніх фахівців $з$ дизайну. мистецька освіта: зміст, технології, менеджмент, 10, с. 5-16.

Прохорчук, П. С., 2019. Критерії, компоненти, показники та рівні формування професійно-етичної культури майбутніх графічних дизайнерів. Молодь і ринок, 4(171), с. 173-177.

Прохорчук, П. С., 2019. Методологічні підходи до формування професійно-етичної культури графічних дизайнерів. Молодий вчений, 4 (68), с. 70-73. DOI: https://doi.org/10.32839/2304-5809/2019-4-68-16.

Прохорчук, О. М., 2016. Педагогічні умови формування дослідницької компетентності бакалаврів соціальної педагогіки. Науковий вісник Національного університету біоресурсів і природокористування Украӥни, 239, с. 207-216.

Прохорчук П., 2018. Проблема формування професійно-етичної культури у психолого-педагогічній літературі. Науковий вісник Інституту професійно-технічної освіти НАПН України. Професійна педагогіка, 16, с. 6873. DOI: https://doi.org/10.32835/2223-5752.2018.16.68-73.

Бусел, Р. Т., 2005. Великий тлумачний словник сучасної української мови. Київ; Ірпінь: Перун.

Шинкарук, В. І., 2002. Філософський енциклопедичний словник. Київ: Абрис.

\section{Translated \& Transliterated}

Kalenskyi, A. A., 2016. Komponenty profesiino-pedahohichnoi etyky [Components of vocational teachers' ethics]. Naukovyi visnyk Natsionalnoho universytetu bioresursiv i pryrodokorystuvannia Ukrainy [Scientific Herald of National University of Life and Environmental Sciences of Ukraine], 233, c. 106-111, [in Ukrainian].

Fursa, O. O. ta Orlov, V. F., 2015. Problemy proektuvannia profesiinoi kariery maibutnikh fakhivtsiv z dyzainu [The problems of designing future professional career design specialists.]. Mystetska osvita: zmist, tekhnolohii, menedzhment [Artistic education: maintenance, technologies, management], 10, s. 5-16, [in Ukrainian].

Prokhorchuk, P. S., 2019. Kryterii, komponenty, pokaznyky ta rivni formuvannia profesiino-etychnoi kultury maibutnikh hrafichnykh dyzaineriv. [Criteria, components, indicators and levels of formation of professional and ethical culture of future graphic designers]. Molod i rynok: zb. nauk [Youth and market], 4(171), s. 173-177, [in Ukrainian].

Prokhorchuk, P. S., 2019. Metodolohichni pidkhody do formuvannia profesiino-etychnoi kultury hrafichnykh dyzaineriv [Methodological approaches to formation professional and ethic culture of graphic designers]. Molodyy vchenyy [Young scientist], 4 (68), s.70-73 [in Ukrainian]. DOI: https://doi.org/10.32839/2304-5809/2019-4-68-16.

Prokhorchuk, O. M., 2016. Pedahohichni umovy formuvannia doslidnytskoi kompetentnosti bakalavriv sotsialnoi pedahohiky [Pedagogical conditions for forming social pedagogy bachelors' research competence]. Naukovyi visnyk Natsionalnoho universytetu bioresursiv i pryrodokorystuvannia Ukrainy [Scientific Herald of National University of Life and Environmental Sciences of Ukraine], 239, s. 207-216, [in Ukrainian].

Prokhorchuk P., 2018. Problema formuvannia profesiino-etychnoi kultury u psykholoho-pedahohichnii literaturi [The problem of forming the professional and ethical culture in psychological and pedagogical literature]. Naukovyi visnyk Instytutu profesiino-tekhnichnoi osvity NAPN Ukrainy. Profesiina pedahohika [Scientific Herald of the Institute of Vocational Education and Training of the National Academy of Pedagogical Sciences of Ukraine. Vocational pedagogy], 16, s. 68-73. DOI: https://doi.org/10.32835/2223-5752.2018.16.68-73, [in Ukrainian].

Busel, R. T., 2005. Velykyi tlumachnyi slovnyk suchasnoi ukrainskoi movy [Large explanatory dictionary of modern Ukrainian language]. Kyiv; Irpin: Perun, [in Ukrainian].

Shynkaruk, V. I., 2002. Filosofskyi entsyklopedychnyi slovnyk [Philosophical encyclopaedic dictionary]. Kyiv: Abrys, [in Ukrainian].

\section{Модель формування професійно-етичної культури майбутніх графічних дизайнерів у коледжах}

\author{
Прохорчук Поліна,
}

аспірантка Інституту професійно-технічної освіти НАПН України

Реферат. Модель формування професійно-етичної культури майбутніх графічних дизайнерів охарактеризовано в контексті етичної підготовки фахівців у коледжах. У процесі дослідження застосовано низку методів: аналіз, синтез, узагальнення, систематизацію, вивчення попереднього досвіду, анкетування та експертну оцінку. Вперше обгрунтовано структуру та зміст моделі формування професійно-етичної культури майбутніх графічних дизайнерів у коледжах. Виокремлено такі ії структурні блоки: методологічний (визначає цілеспрямоване формування професійноетичної культури майбутніх графічних дизайнерів), змістовно-технологічний (характеризує педагогічні умови, тех- 
нології, методи, форми та засоби формування професійно-етичної культури), діяльнісно-коригувальний (обгрунтовує критерії та рівні сформованості професійно-етичної культури майбутніх графічних дизайнерів).

На основі узагальнення різних теоретичних положень, що склали методологічний концепт дослідження, визначено провідні концептуальні підходи до реалізації його мети і завдань, а саме: аксіологічний, культурологічний, системний, синергетичний, діяльнісний, технологічний, особистісно-орієнтований. Охарактеризовано етапи, що визначають послідовність процесу формування професійно-етичної культури майбутніх графічних дизайнерів та його керованість. Розроблена модель розкриває логіку дослідницької роботи щодо цілеспрямованого розвитку етичних норм та цінностей студентів мистецьких коледжів; слугує засобом визначення професійноетичної культури як педагогічної категорії; прогнозує результати формування професійно-етичної культури майбутніх графічних дизайнерів; унаочнює найважливіші змістові блоки досліджуваного процесу; дає змогу чітко прослідковувати взаємозв'язки окремих структурних складових. Визначено перспективи подальших наукових розвідок, пов'язаних з розробленням технології проектування змісту етично орієнтованої професійної підготовки молодших спеціалістів графічного дизайну у закладах фахової передвищої освіти.

Ключові слова: професійна освіта, професійно-етична культура, графічні дизайнери, модель, моделювання.

Received: 10 Aprile 2019

Accepted: 19 May 2019 